\title{
Formulation and quality assessment of protein rich sesame Chikki - Indigenous energy bar
}

\section{Snehal D. Pande and Shrutika K. Deo}

See end of the Paper for authors' affiliation

Correspondence to :

Snehal D. Pande

MIT College of Food

Technology, Aurangabad

(M.S.) India

Email : englestar44@gmail.com
- Abstract : 'Brittle' is commonly known as Chikki-it's an indigenous sweet snack, mostly liked by all age groups, also possesses nutritional importance in it. In present study utilization of sesame (Sesamum indicum) is carried out in Chikki to evaluate the acceptance of consumers towards $\mathrm{S}_{1}$ to $\mathrm{S}_{4}$ samples i.e. $\mathrm{S}_{1}$ as Raw sesame and Jaggery, $\mathrm{S}_{2}$ as Roasted sesame and Jaggery, $\mathrm{S}_{3}$ as Raw sesame and Sugar while $S_{4}$ as Roasted sesame and Sugar. Sample $S_{1}, S_{2}, S_{3}$ and $S_{4}$ were subjected to proximate analysis, Textural Analysis, organoleptic evaluation and statistical analysis (ANOVA). Results showed the more hardness in Roasted sesame and sugar sample $\left(\mathrm{S}_{4}\right)$ 201.70 MJ. Organoleptic properties revealed that raw sesame and sugar sample $\left(\mathrm{S}_{4}\right)$ is acceptable permutation of Chikki followed by roasted sesame and jaggery sample $\left(\mathrm{S}_{2}\right)$.

- Key words : Sesame Chikki, ANOVA, Texture analysis

- How to cite this paper : Pande, Snehal D. and Deo, Shrutika K. (2018). Formulation and quality assessment of protein rich sesame Chikki - Indigenous energy bar. Internat. J. Agric. Engg., 11(Sp. Issue) : 11-14, DOI: 10.15740/HAS/IJAE/11.Sp. Issue/11-14. 